\title{
GIZI LEBIH SEBAGAI TANTANGAN BARU DAN IMPLIKASINYA TERHADAP KEBIJAKAN PEMBANGUNAN KESEHATAN NASIONAL ${ }^{1,2}$
}

\author{
Hamam Hadi
}

\section{PENDAHULUAN}

Sebagai negara yang sedang berkembang dan sedang membangun, bangsa Indonesia masih memiliki beberapa ketertinggalan dan kekurangan jika dibandingkan negara lain yang sudah lebih maju. Di bidang kesehatan, bangsa Indonesia masih harus berjuang memerangi berbagai macam penyakit infeksi dan kurang gizi yang saling berinteraksi satu sama lain menjadikan tingkat kesehatan masyarakat Indonesia tidak kunjung meningkat secara signifikan. Ironisnya, di beberapa daerah lain atau pada sekelompok masyarakat Indonesia yang lain terutama di kota-kota besar, masalah kesehatan masyarakat utama justru dipicu dengan adanya kelebihan gizi; meledaknya kejadian obesitas di beberapa daerah di Indonesia akan mendatangkan masalah baru yang mempunyai konsekuensikonsekuensi serius bagi pembangunan bangsa Indonesia khususnya di bidang kesehatan. Pendek kata, masih tingginya prevalensi kurang gizi di beberapa daerah dan meningkatnya prevalensi obesitas yang dramatis di beberapa daerah yang lain akan menambah beban yang lebih kompleks dan harus dibayar mahal oleh bangsa Indonesia dalam upaya pembangunan bidang kesehatan, sumberdaya manusia dan ekonomi.

\section{GIZI LEBIH DAN OBESITAS SEBAGAI SINDROMA DUNIA BARU (NEW WORLD SYNDROME)}

Jika gizi kurang banyak dihubungkan dengan penyakit-penyakit infeksi (meskipun tidak seluruhnya benar), maka gizi lebih dan obesitas dianggap sebagai sinyal pertama dari munculnya kelompok penyakitpenyakit noninfeksi (Non Communicable Diseases) yang sekarang ini banyak terjadi di negara-negara maju maupun negara-negara sedang berkembang. Fenomena ini sering diberi nama "New World Syndrome" atau Sindroma Dunia Baru (1) dan ini telah menimbulkan beban sosial-ekonomi serta kesehatan masyarakat yang sangat besar di negara-negara sedang berkembang termasuk Indonesia. Tingginya angka obesitas, diabetes (NIDDM), hipertensi, dyslipidemia, dan penyakit-penyakit kardiovakuler disertai dengan tingginya prevalensi merokok dan penyalah-gunaan obat sangat erat hubungannya dengan proses modernisasi/akulturasi dan meningkatnya kemakmuran bagi sekelompok masyarakat. Adalah Sindroma Dunia Baru yang bertanggungjawab terhadap tingginya morbiditas dan mortalitas yang tidak proporsional di negara-negara yang baru saja mencapai kategori negara maju termasuk negara-negara Eropa Timur dan di antara kelompok etnis minoritas dan kelompok yang kurang beruntung di negaranegara maju.

Modernisasi dan kecenderungan pasar global yang mulai dirasakan di sebagian besar negara-negara berkembang telah memberikan kepada masyarakat beberapa kemajuan dalam standar kehidupan dan pelayanan yang tersedia. Akan tetapi, modernisasi juga telah membawa beberapa konsekuensi negatif yang secara langsung dan tidak langsung telah mengarahkan terjadinya penyimpangan-penyimpangan pola makan dan aktivitas fisik yang berperanan penting terhadap munculnya obesitas.

\section{BESARNYA MASALAH GIZI LEBIH}

Obesitas sering didefinisikan sebagai kondisi abnormal atau kelebihan lemak yang serius dalam jaringan adiposa sedemikian sehingga mengganggu kesehatan (2). Saat ini terdapat bukti bahwa prevalensi kelebihan berat badan (overweight) dan obesitas meningkat sangat tajam di seluruh dunia yang mencapai tingkatan yang membahayakan. Kejadian obesitas di negara-negara maju seperti di negara-negara Eropa, USA, dan Australia telah mencapai tingkatan epidemi. Akan tetapi hal ini tidak hanya terjadi di negara-negara maju, di beberapa negara berkembang obesitas justru telah menjadi masalah kesehatan yang lebih serius. Sebagai contoh, $70 \%$ dari penduduk dewasa Polynesia di Samoa masuk kategori obes (3).

Magister Gizi dan Kesehatan UGM, Yogyakarta

Dipresentasikan pada pidato pengukuhan jabatan guru besar pada Fakultas Kedokteran UGM, Yogyakarta 
Prevalensi overweight dan obesitas meningkat sangat tajam di kawasan Asia-Pasifik. Sebagai contoh, 20,5\% dari penduduk Korea Selatan tergolong overweight dan 1,5\% tergolong obes. Di Thailand, $16 \%$ penduduknya mengalami overweight dan 4\% mengalami obes. Di daerah perkotaan Cina, prevalensi overweight adalah $12,3 \%$ pada laki-laki dan $14,4 \%$ pada perempuan, sedang di daerah pedesaan prevalensi overweight pada laki-laki dan perempuan masing-masing adalah 5,3\% dan 9,8\% (4).

Obesitas tidak hanya ditemukan pada penduduk dewasa tetapi juga pada anak-anak dan remaja. Penelitian yang dilakukan di Malaysia akhir-akhir ini menunjukkan bahwa prevalensi obesitas mencapai $6,6 \%$ untuk kelompok umur 7 tahun dan menjadi $13,8 \%$ pada kelompok umur 10 tahun (5). Di Cina, kurang lebih 10\% anak sekolah mengalami obes, sedangkan di Jepang prevalensi obesitas pada anak umur 6-14 tahun berkisar antara $5 \%$ s/d $11 \%(6)$.

Bersamaan dengan meningkatnya obesitas, prevalensi diabetes type 2 juga meningkat sangat tajam dan peningkatan ini diperkirakan akan terus berlanjut. Saat ini jumlah penduduk di wilayah Asia-Pasifik yang menderita diabetes type 2 diperkirakan mencapai 30 juta orang dan diperkirakan 120 juta dari penduduk dunia saat ini mengalami diabetes type 2. Pada tahun 2010 diperkirakan 210 juta penduduk dunia mengalami diabetes type 2, 130 juta diantaranya dikawasan Asia Pasifik (7).

Data tentang obesitas di Indonesia belum bisa menggambarkan prevalensi obesitas seluruh penduduk, akan tetapi data obesitas pada orang dewasa yang tinggal di ibukota propinsi seluruh Indonesia cukup untuk menjadi perhatian kita. Survei nasional yang dilakukan pada tahun 1996/1997 di ibukota seluruh propinsi Indonesia menunjukkan bahwa $8,1 \%$ penduduk laki-laki dewasa ( $>=18$ tahun) mengalami overweight (BMI 2527) dan $6.8 \%$ mengalami obesitas, $10,5 \%$ penduduk wanita dewasa mengalami overweight dan $13,5 \%$ mengalami obesitas. Pada kelompok umur 40-49 tahun overweight maupun obesitas mencapai puncaknya yaitu masing-masing $24,4 \%$ dan $23 \%$ pada laki-laki dan $30,4 \%$ dan $43 \%$ pada wanita (8).

Sampai dengan saat ini belum ada data nasional tentang obesitas pada anak sekolah dan remaja. Akan tetapi beberapa survei yang dilakukan secara terpisah di beberapa kota besar menujukkan bahwa prevalensi obesitas pada anak sekolah dan remaja cukup tinggi. Pada anak SD prevalensi obesitas mencapai 9,7\% di Yogyakarta (5) dan 15,8\% di Denpasar (6). Survei obesitas yang dilakukan akhir-akhir ini pada anak remaja siswa/ siswi SLTP di Yogyakarta menunjukkan bahwa 7,8\% remaja di perkotaan dan $2 \%$ remaja di daerah pedesaan mengalami obesitas (7). Angka prevalensi obesitas di atas baik pada anak-anak maupun orang dewasa sudah merupakan warning bagi pemerintah dan masyarakat luas bahwa obesitas dan segala implikasinya sudah merupakan ancaman yang serius bagi masyarakat Indonesia khususnya di kota-kota besar.

\section{KONSEKUENSI GIZI LEBIH}

Obesitas meningkatkan risiko kematian untuk semua penyebab kematian. Orang yang mempunyai berat badan $40 \%$ lebih berat dari berat badan rata-rata populasi mempunyai risiko kematian 2 kali lebih besar dibandingkan orang dengan berat badan rata-rata (8). Kenaikan mortalitas di antara penderita obes merupakan akibat dari beberapa penyakit yang mengancam kehidupan seperti diabetes tipe 2 , penyakit jantung, penyakit kandung kemih, kanker gastrointestinal dan kanker yang sensitif terhadap perubahan hormon. Orang obes juga mempunyai risiko yang lebih besar untuk menderita beberapa masalah kesehatan seperti back pain, arthritis, infertilitas, dan fungsi psychososial yang menurun (9).

Pada anak-anak, obesitas dapat menyebabkan beberapa penyakit kronis meliputi gangguan metabolisme glukosa, resistensi insulin, diabetes tipe 2 pada remaja, hipertensi, dyslipidemia, steatosis hepatic, gangguan gastrointestinal, dan obstruksi pernafasan pada waktu tidur. Lebih khusus lagi, obesitas pada remaja di kawasan AsiaPasifik berhubungan dengan diabetes tipe 2 pada umur yang lebih muda (10).

Banyak studi yang menunjukkan adanya kecenderungan anak obes untuk tetap obes pada masa dewasa (11), yang dapat berakibat pada kenaikan risiko penyakit dan gangguan yang berhubungan dengan obesitas pada masa kehidupan berikutnya. Gangguan psychososial juga sering menjadi masalah bagi anak-anak obes dengan diketahuinya obesitas oleh mereka sendiri dan orang lain sebagai handicap yang serius.

\section{MENGAPA OBESITAS BISA MELEDAK DI HAMPIR SELURUH DUNIA?}

\section{Ketidak-seimbangan Energi}

Secara singkat dapat dikatakan bahwa obesitas merupakan akibat dari adanya ketidak-seimbangan antara asupan energi (energy intake) yang melebihi energi yang digunakan (energy expenditure). Dalam keadaan normal, keseimbangan energi berubah-ubah dari makanan satu kemakanan yang lain, dari hari ke hari, minggu ke minggu tanpa ada perubahan kekal dalam cadangan tubuh atau berat badan. Beberapa mekanisme fisiologis berperan penting dalam diri individu untuk menyeimbangkan keseluruhan asupan energi dengan keseluruhan energi yang digunakan dan untuk menjaga berat badan stabil dalam 
jangka waktu yang cukup panjang. Obesitas hanya akan muncul apabila terjadi keseimbangan energi positif untuk periode waktu yang cukup panjang (9).

Mekanisme fisiologis yang bertanggung jawab terhadap terjadinya obesitas tidak diketahui secara sempurna. Akan tetapi, sekarang terdapat bukti yang makin jelas tentang adanya beberapa mekanisme yang memberi sinyal dalam usus halus, jaringan adiposa dan otak, dan mungkin jaringan lain yang dapat memberikan gambaran tentang arus asupan zat gizi, distribusi dan metabolismenya, dan atau penyimpanannya. Keseluruhan mekanisme ini dikordinasikan dalam otak dan mengarahkan pada perubahan pola makan, aktifitas fisik, dan metabolisme tubuh sedemikian rupa sehingga cadangan energi dalam tubuh dapat dijaga. Penemuan akhir-akhir ini tentang adanya hormon leptin, yang disekresi oleh adipocyte dalam jumlah yang proporsional terhadap cadangan trigliserida dan mengikat diri dengan reseptor di hipothalamus memberikan gambaran yang menarik tentang sistem sinyal pengaturan yang mungkin (possible regulatory signal systems) yang berfungsi untuk memelihara keseimbangan energi (9). Akan tetapi masih banyak yang perlu dipelajari lebih lanjut tentang sistem tersebut.

Pada masyarakat tradisional, di mana orang-orang cenderung melakukan aktivitas fisik dan dengan catatan bahwa kesediaan makanan tidak terbatas maka hanya sedikit orang yang mempunyai masalah gizi; baik kurang gizi ataupun kelebihan gizi. Diperkirakan bahwa tubuh manusia mempunyai pertahanan lebih kuat untuk melawan kurang gizi dan kehilangan berat badan dibandingkan pertahanan untuk melawan konsumsi yang berlebih dan kelebihan berat badan.

\section{Pola Makan dan Aktivitas Fisik}

Faktor-faktor diet dan pola aktivitas fisik mempunyai pengaruh yang kuat terhadap keseimbangan energi dan dapat dikatakan sebagai faktor-faktor utama yang dapat diubah (modifiable factors) yang melalui faktor-faktor tersebut banyak kekuatan luar yang memicu pertambahan berat badan itu bekerja. Lebih jelasnya, diet tinggi lemak dan tinggi kalori dan pola hidup kurang gerak (sedentary lifestyles) adalah dua karakteristik yang sangat berkaitan dengan peningkatan prevalensi obesitas di seluruh dunia (9).

Beberapa data cross-sectional menunjukkan adanya hubungan negatif antara BMI dan aktivitas fisik $(12,13)$, yang menunjukkan bahwa orang obes atau gemuk mempunyai aktivitas kurang dibandingkan orang-orang yang ramping. Akan tetapi hubungan tersebut tidak bisa menggambarkan adanya hubungan sebab-akibat dan sulit untuk menentukan apakah orang obes mempunyai aktivitas fisik kurang oleh karena obesitasnya atau aktivitas fisik yang kurang menjadikan mereka obes. Namun demikian, beberapa hasil studi dengan rancangan penelitian lain menunjukkan bahwa rendahnya dan menurunnya aktivitas fisik merupakan faktor yang paling bertanggungjawab terjadinya obesitas. Sebagai contoh, obesitas tidak terjadi pada para atlet yang aktif sedangkan para atlet yang berhenti melakukan latihan/olahraga lebih sering mengalami kenaikan berat badan dan kegemukan $(14,15)$. Lebih lanjut, kecenderungan sekuler (Secular trend) dalam kenaikan prevalensi obesitas paralel dengan penurunan aktivitas fisik dan peningkatan perilaku hidup kurang gerak yang selanjutnya disebut SEDENTARIAN (sedentary). Salah satu contoh studi yang paling baik yang menyokong hipotesis ini ialah yang dikemukakan oleh Prentice \& Jebb (16). Menggunakan proksi kasar tentang ketidak-aktifan seperti jumlah waktu yang digunakan untuk menonton televisi atau jumlah mobil perkeluarga, penelitian ini menunjukkan bahwa penurunan aktivitas fisik dan atau peningkatan perilaku hidup sedentarian mempunyai peranan penting dalam peningkatan berat badan dan terjadinya obesitas. Studi prospektif lain menunjukkan bahwa jumlah waktu yang digunakan untuk menonton televeisi oleh anak-anak merupakan prediktor tinggi rendahnya BMI beberapa tahun kemudian, dan tingkat aktivitas fisik yang rendah pada orang dewasa dapat dijadikan sebagai prediktor penting penambahan berat badan yang substansial $(>5$ $\mathrm{kg}$ ) dalam 5 tahun ke depan (15).

Dalam studi yang dilakukan pada tahun 2003 dengan melibatkan 4.747 siswa/siswi SLTP Kota Yogyakarta dan 4.602 siswa/siswi SLTP Kabupaten Bantul ditemukan bahwa 7,8\% remaja di Kota Yogyakarta dan 2\% remaja Kabupaten Bantul mengalami obesitas (cut off IMT>=95 percentile NCHS). Rata-rata asupan energi anak obes di kota Yogyakarta adalah 2818,3 \pm 499,4 kkal/hari sedangkan rata-rata asupan energi remaja non-obes dikota Yogyakarta adalah 2210,4 $\pm 329,8 \mathrm{kkal} / \mathrm{hari}$. Dengan kata lain bahwa asupan energi remaja obes adalah $607,9 \mathrm{kkal} /$ hari lebih tinggi dibandingkan remaja non-obes. Yang menarik ialah bahwa remaja obes 2-3 kali lebih sering mengkonsumsi fast food seperti Mac Donald, Kentucky Fried Chicken, Pizza, dsb. Remaja obes dalam kesehariannya mempunyai waktu untuk nonton TV lebih lama dibandingkan remaja non-obes (3.14 $\pm 1.56 \mathrm{jam} / \mathrm{hr}$ VS $2.62 \pm 1.67 \mathrm{jam} / \mathrm{hari})$. Remaja obes dalam kesehariannya mempunyai waktu untuk aktifitas ringan seperti baca buku, duduk-duduk, main play stasion, dsb lebih panjang (12.20 $\pm 1.94 \mathrm{jam} / \mathrm{hr}$ VS $11.36 \pm 1.76 \mathrm{jam} /$ hr) dibandingkan remaja non-obes. Sebaliknya remaja obes mempunyai waktu untuk melakukan aktivitas sedang atau berat seperti naik sepeda, sepak bola, basket dsb lebih pendek dibandingkan remaja non-obes. Dalam analisis lebih lanjut ditemkan bahwa remaja dengan asupan energi 
normal ( $<2.200 \mathrm{kkal} / \mathrm{hari})$ tetapi nonton TV $>=3$ jam/hari mempunyai risiko obesitas 2.7 kali lebih tinggi dibandingkan remaja yang asupan energi normal $<2.200$ $\mathrm{kkal} / \mathrm{hari}$ dan waktu nonton TV $<3 \mathrm{jam} / \mathrm{hari}$. Remaja yang asupan energinya tinggi ( $>=2.200 \mathrm{kkal} / \mathrm{hari}$ ) dan mempunyai waktu nonton TV $>=3 \mathrm{jam} / \mathrm{hari}$ mempunyai risiko menderita obes 12.3 kali lebih tinggi dibandingkan remaja yang asupan energi $<2.200 \mathrm{kkal} / \mathrm{hari}$ dan waktu nonton TV $<3$ jam/hari (7). Studi ini menunjukkan adanya interaksi yang bersifat additif, multiplikatif antara gaya hidup sedentarian dan diet tinggi kalori.

\section{PERUBAHAN POLA PENYAKIT UTAMA DI INDONESIA}

Berdasarkan data mutakhir (17) yang diambil dari berbagai kota dan kabupaten yang mewakili daerah fiskal rendah, sedang dan tinggi ditemukan bahwa pola penyakit utama masih didominasi oleh penyakit-penyakit infeksi. Yang menarik ialah bahwa penyakit ISPA masih menempati urutan pertama di semua daerah baik kabupaten maupun kota disusul oleh penyakit infeksi yang lain seperti malaria, dan penyakit kulit. Akan tetapi yang lebih menarik lagi ialah bahwa pada urutan berikutnya, yakni pada urutan $4 \mathrm{~s} / \mathrm{d} 6$ sudah banyak ditempati oleh penyakit noninfeksi khususnya penyakit hipertensi. Penyakit hipertensi ini naik peringkat dari urutan $8 \mathrm{~s} / \mathrm{d}$ 10 pada tahun 1980-an menjadi urutan 4-6 pada tahuntahun belakangan ini. Penyebab kematian utama di rumah sakit juga ditempati oleh penyakit-penyakit noninfeksi secara berturut-turut yaitu stroke, gagal ginjal, penyakit jantung lainnya, perdarahan intra-cranial, dan diabetes melitus, serta penyakit jantung iskhemik (8). Hal ini mungkin terjadi akibat adanya perubahan pola makan dan gaya hidup penduduk Indonesia di samping perubahan struktur penduduk Indonesia yang ditandai dengan meningkatnya proporsi penduduk usia produktif dan lansia serta menurunnya proporsi penduduk balita. (18).

Hipertensi hanyalah salah satu penyakit noninfeksi dari sekian banyak penyakit yang erat kaitannya dengan obesitas dan mudah terdeteksi dengan peralatan medis sederhana yang tersedia di puskesmas. Penyakitpenyakit noninfeksi lain yang lebih serius dan sangat erat hubungannya dengan obesitas seperti penyakit-penyakit kardiovaskuler, diabetes mellitus dsb, tidak bisa terungkap dengan menggunakan data dari puskesmas oleh karena penderita penyakit-penyakit tersebut lebih sering langsung berobat ke spesialis atau ke rumah sakit.

Secara keseluruhan, data epidemiologis saat ini menunjukkan bahwa prevalensi diabetes mellitus di Indonesia berkisar 1,5 s/d 2,3\%. Akan tetapi, penelitian terakhir yang dilakukan di kota besar seperti Jakarta menunujukkan bahwa prevalensi diabetes melitus mencapai $12,8 \%$ dari populasi penduduk dewasa (19).
Dengan sifat penyakit diabetes mellitus yang tidak dapat disembuhkan secara sempurna dan hanya bisa dikontrol, maka dengan kenaikan insidensi diabetes mellitus yang terjadi akibat perubahan pola makan dan gaya hidup diperkirakan prevalensi diabetes mellitus di Indonesia pada tahun 2010 naik lebih dari 100\%.

\section{NILAI EKONOMIS DARI OVERWEIGHT DAN OBESITAS}

Nilai ekonomi dari obesitas terdiri dari 3 komponen yaitu; Pertama, Direct cost (biaya langsung) yakni biaya bagi individu dan petugas yang berkaitan dengan upaya penyembuhan obesitas itu sendiri; Kedua, opportunity cost (biaya kesempatan) yakni biaya yang menyangkut individu akibat kehilangan kesempatan sosial dan personal sebagai akibat dari obesitas seperti adanya kematian dini, dan penyakit-penyakit yang muncul akibat obesitas; Ketiga, indirect cost (biaya tidak langsung) yaitu biaya yang diukur dengan adanya kehilangan penghasilan oleh karena tidak dapat melakukan pekerjaan sehari-hari sebagaimana mestinya orang yang tidak mengalami obesitas.

Sampai dengan saat ini di Indonesia dan negaranegara berkembang yang lain belum tersedia data tentang besarnya nilai ekonomi dari obesitas, baik biaya langsung maupun biaya tidak langsung. Akan tetapi beberapa studi di negara maju menunjukkan bahwa biaya langsung dari obesitas per tahun mencapai 464 juta Aus\$ di Australia (20), 12 Milyar FF di Perancis (21), 1 Milyar NLG di Belanda (22), dan 45.8 Milyar US \$ di Amerika Serikat (23). Besar biaya obesitas tersebut merupakan $4-7 \%$ dari total biaya kesehatan nasional negara masingmasing. Yang menarik ialah bahwa 53\% sampai dengan $60 \%(20,21)$ dari biaya langsung ini diatributkan pada penyakit hipertensi dan penyakit jantung koroner.

Data tentang biaya tidak langsung dari obesitas masih sangat terbatas, akan tetapi suatu studi di Amerika yang dilakukan akhir-akhir ini menyebutkan bahwa biaya tidak langsung dari obesitas mencapai 23.3 Milyar US\$ per tahun, yang terdiri dari 4 Milyar US $\$$ biaya kehilangan produktivitas atau Rp25.591.480,00 hari kerja, dan 19,3 Milyar US\$ biaya yang muncul akibat kematian dini dengan penyebab kematian utama penyakit-penyakit yang berkaitan dengan obesitas.

Secara keseluruhan dapat disimpulkan dari berbagai studi bahwa obesitas merupakan salah satu komponen terbesar dari budget nasional di bidang kesehatan. Meskipun belum banyak studi tentang besar biaya yang muncul akibat obesitas di negara-negara berkembang termasuk Indonesia, beban biaya ekonomi yang terus meningkat dari adanya penyakit-penyakit kronis pada orang dewasa di negara-negara tersebut telah diketahui oleh beberapa lembaga Internasional seperti WHO, dan 
World Bank. Biaya nyata dari terapi obesitas di negaranegara berkembang lebih besar dibandingkan di negaranegara maju oleh karena adanya beban tambahan akibat impor peralatan-peralatan dan obat-obatan dan untuk keperluan pelatihan tenaga kesehatan (9).

\section{IMPLIKASI KEBIJAKAN}

Dari uraian di atas jelas bahwa beban pembangunan bidang kesehatan nasional akan semakin berat dengan adanya masalah gizi ganda karena baik gizi kurang maupun gizi lebih sangat erat kaitannya dengan aspek kesehatan yang lain. Masih besarnya beban masalah kesehatan yang bersumber dari defisiensi gizi dan penyakit infeksi di satu sisi dan makin meningkatnya masalah kesehatan yang bersumber dari masalah gizi lebih dan penyakit-penyakit degeneratif di sisi lain perlu diantisipasi dengan melakukan perubahan kebijakan yang mendasar dalam upaya pelayanan kesehatan, baik upaya pelayanan kesehatan per-orangan maupun upaya pelayanan kesehatan masyarakat.

Dengan terbatasnya sumber daya yang ada dan semakin terbatasnya kemampuan pemerintah menyediakan anggaran di saat beban pembangunan kesehatan meningkat maka kebijakan yang berimbang dan simultan antara upaya-upaya kesehatan promotif dan preventif di satu sisi dan upaya-upaya kesehatan kuratif/ rehabilitatif di sisi lain dengan meningkatkan partisipasi masyarakat secara luas merupakan hal yang tidak hanya krusial, tetapi juga merupakan satu-satunya pendekatan yang sensibel untuk perencanaan kebijakan kesehatan masyarakat di Indonesia.

Strategi yang ditujukan untuk pencegahan obesitas dan implikasinya juga merupakan strategi yang lebih mudah, lebih murah dan lebih efektif dibandingkan strategi pengobatan obesitas oleh karena beberapa alasan; 1) obesitas terus meningkat dari waktu ke waktu, dan sekali obesitas terjadi maka sulit untuk mengobati (23); 2) Konsekuensi dari obesitas merupakan stress fisik dan metabolik yang bersifat kumulatif dari kelebihan berat badan yang terjadi dalam periode waktu yang cukup lama, dan mungkin tidak dapat pulih kembali dengan sempurna dengan mengurangi berat badan saja (24); 3) Jika di negara maju saja sumber daya pelayanan kesehatan tidak lagi mencukupi kebutuhan pengobatan untuk semua kejadian obesitas dan penyakit terkait oleh karena adanya peningkatan obesitas yang sangat dramatis, maka tanpa adanya program pencegahan yang efektif, sumberdaya yang ada di negara-negara berkembang termasuk Indonesia akan segera terkuras habis (exhausted) untuk pengobatan obesitas dan penyakit-penyakit degeneratif lain yang relatif lebih mahal dan membutuhkan tehnologi canggih (9).
Adalah suatu ironi bahwa kenyataan di lapangan pada saat ini, perhatian terhadap upaya-upaya kesehatan promotif dan preventif sangat kecil dibandingkan perhatian yang diberikan pada upaya-upaya kuratif-rehabilitatif. Relatif kecilnya perhatian pemerintah terhadap upayaupaya kesehatan promotif-preventif dapat dilihat dari relatif kecilnya anggaran yang dialokasikan. Fakta di lapangan menunjukkan bahwa anggaran yang dialokasikan untuk upaya-upaya promotif-preventif tidak mencapai $10 \%$ dari total anggaran kesehatan. Sebaliknya, anggaran biaya yang dialokasikan untuk upaya-upaya kesehatan kuratif mencapai 60 hingga $85 \%$ dari total anggaran bidang kesehatan.

Tingginya kejadian luar biasa baik untuk penyakit menular seperti demam berdarah, malaria dsb maupun gizi buruk akhir-akhir ini merupakan dampak dari "Kebijakan pembangunan kesehatan yang kedodoran dan bersifat responsif "(delayed and responsive health policy)" istilah saya, suatu kebijakan kesehatan yang lebih bersifat responsif dan kagetan ketimbang kebijakan kesehatan yang antisipatif terhadap masalah-masalah kesehatan yang dirumuskan dengan cara yang lebih sistematis berdasarkan fakta di lapangan (evidence based), kebijakan kesehatan yang lebih bersifat simptomatif dan populis ketimbang kebijakan yang bersifat kausatif.

\section{PERAN PEMERINTAH DAERAH DAN WAKIL RAKYAT (DPRD/DPR)}

Dengan adanya undang-undang tentang otonomi daerah maka peran kabupaten/kota menjadi sangat menentukan keberhasilan pembangunan termasuk pembangunan bidang kesehatan. Namun demikian, secara keseluruhan dapat dikatakan bahwa komitmen pemerintah daerah terhadap pembangunan bidang kesehatan masih kurang memadai. Perhatian utama dari sebagian besar pemerintah daerah lebih ditujukan pada upaya pembangunan infrastruktur, sarana-prasarana dan pengembangan wilayah (INPRASWIL). Pembangunan yang yang bersifat nonfisik dan tidak dapat dilihat hasilnya dalam waktu dekat seperti pembangunan kesehatan umumnya kurang mendapat perhatian. Di samping itu, sering alokasi anggaran kesehatan tidak memihak kepada kepentingan rakyat banyak, tetapi untuk keperluan sekelompok penduduk perkotaan atau mungkin hanya menguntungkan penentu kebijakan saja. Tidak jarang pemerintah daerah dan DPRD, di daerah miskin sekalipun lebih mengutamakan pendirian rumah sakit baru dengan peralatan canggih dan mahal daripada memperbanyak, memperbaiki, melengkapi peralatan dan meningkatkan kapasitas sumber daya manusia puskesmas yang sudah ada, dengan impian bahwa rumah sakit tersebut dapat dijadikan sapi perah dan sebagai salah satu sumber utama 
Pendapatan Asli Daerah (PAD). Bahkan ada daerah yang enggan mengalokasikan anggaran biaya untuk pembelian vaksin dan kapsul vitamin A dengan cukup untuk bayi dan balita, karena lebih mementingkan anggaran untuk peralatan canggih (17). Ini sama halnya mereka berharap agar masyarakatnya yang masih miskin lebih sering menderita penyakit sehingga memberikan pemasukan pendapatan daerah dengan kemiskinan dan penderitaannya. Mereka tidak berpikir sebaliknya memberikan investasi yang cukup untuk membangun masyarakat yang sehat (bergizi tentunya), cerdas, dan produktif sehingga dapat memberikan PAD yang lebih besar serta membangun daerahnya dengan kecerdasan dan ketangkasannya dan bukan dengan derita dan nestapa.

Advokasi terhadap pemerintah dan para wakil rakyat daerah lalu menjadi sangat dibutuhkan. Ironisnya, advokasi dari Dinas Kesehatan kepada para wakil rakyat dan pemerintah daerah pada umumnya masih sangat minim dan kurang efektif. Ada beberapa alasan mengapa advokasi yang dilakukan kurang efektif; 1) advokasi yang dilakukan oleh jajaran Dinkes sering dipersepsikan oleh wakil rakyat daerah tidak lebih sebagai upaya pembelaan terhadap kepentingan jajaran Dinkes; 2) metode advokasi tidak menarik, membosankan, dan berkesan "menggurui" terhadap pihak yang berkuasa; 3) para wakil rakyat merasa bahwa anggota DPRD levelnya lebih tinggi dibandingkan jajaran Dinkes. Oleh karena itu, advokasi terhadap para wakil rakyat dan pemerintah daerah perlu dirancang dan dilaksanakan dengan metode yang lebih menarik, bersifat promotif dan motivatif, serta didukung data dan bukti nyata yang didapat dari penelitian setempat. Agar upaya advokasi lebih efektif tidak cukup dilaksanakan oleh proyek penyuluhan kedinasan, tetapi perlu melibatkan pihak ketiga seperti perguruan tinggi, LSM., dan perlu melibatkan para ahli periklanan swasta serta para pengusaha media masa. Dengan demikian, advokasi yang benar dan efektif memerlukan pembiayaan yang tidak kecil. Ironisnya dalam kenyataan anggaran untuk kegiatan ini biasanya disediakan sekedarnya karena dianggap bukan prioritas.

\section{PERAN PERGURUAN TINGGI}

Sebagaimana disebutkan di atas, masalah gizi dan kesehatan di masa yang akan datang di Indonesia akan semakin komplek, satu sama lain saling terkait dan oleh karena itu, penaganannya pun membutuhkan tenaga yang mempunyai kompetensi lebih tinggi. Pada saat ini tenaga gizi yang bekerja di jajaran Dinas Kesehatan maupun di rumah sakit di seluruh Indonesia sebagian besar lulusan D3 dan D1. Kompetensi minimal yang dimiliki oleh sebagian besar tenaga gizi Indonesia belumlah memenuhi tantangan masalah gizi dan kesehatan saat ini dan apalagi untuk menangani masalah gizi dan kesehatan 10-20 tahun mendatang. Oleh karena itu, perguruan tinggi perlu mengambil peranan dalam mendefinisikan ulang kompetensi ahli gizi Indonesia dan mem-formulasikannya dalam bentuk kurikulm pendidikan tinggi yang dapat memenuhi tuntutan zaman.

\section{KESIMPULAN}

Dari uraian di atas jelas sekali bahwa masaah gizi dan kesehatan di masa datang akan semakin komplek dan itu semua akan menjadi tantangan utama pembangunan bidang kesehatan. Kompleksitas masalah gizi dan kesehatan tersebut menuntut perhatian semua pihak khususnya Departemen Kesehatan RI dalam mengantisipasi masalah kesehatan di masa yang akan datang serta dalam mengambil keputusan kebijakan pembangunan kesehatan. Namun demikian, peran wakil rakyat, pemerintah daerah, masyarakat, perguruan tinggi, dan stakeholder lain juga sangat menentukan keberhasilan dalam menangani masalah gizi dan pembangunan kesehatan di Indonesia.

\section{RUJUKAN}

1. Gracey M. New World Syndrome in Western Australian Aborigines. Clin and Experiment Pharmacol and Physiol 1995;22:220-225.

2. Garrow JS. Obesity and Related Diseases. London: Churchill Livingstone; 1988. p. 1-16.

3. Gillespie S. Major Issues in the Control of Iron Deficiency. The Micronutrient Iniciative. Unicef, Ottawa, Canada; 1998.

4. Inoue S, Zimmet P, and Caterson I. The Asia-Pacific Perspective: Redefining Obesity and its Treatment. Health Communication, Australia; 2000.

5. Ismail D, Herini ES, Hagung P, \& Sadjimin T. Fast Food Consumption and Obesity: Relationship among Elementary School Students in Yogyakarta. Paediatrica Indonesiana 1999.

6. Ito K and Murata M. Diagnostic Criteria of childhood obesity. Japanese journal of Pediatrics 1999;52 (Suppl):1182-96.

7. Hadi H, Hurryati E, Basuki A, Madawati A dan Mahdiah. Obesitas pada Remaja sebagai Ancaman Kesehatan Serius Dekade Mendatang. Makalah disampaikan pada Seminar Nasional "Obesitas pada Remaja"; September 2004; Yogyakarta, Indonesia.

8. Lew EA and Garfinkel L. Variations in Mortality by Weight among 750,000 Men and Women. Journal of Chronic Diseases 1979;32:563-76.

9. WHO. Obesity: Preventing and Managing the Global Epidemic. Geneva: 2000. 
10. Mahoney LT, Burns TL, Stanford W, Thompson BH, Witt JD, Rost CA, Lauer RM. Coronary Risk Factors Measured in Childhood and Young Adult Life are Associated with Coronary Artery Calcification in Young Adults: the Muscatine Study. J Am Coll Cardiol 1996;27:277-84.

11. Guo SS, Roche AF, Chumlea WC, Gardner JD, Siervogel RM. The predictive Value of Childhood Body Mass Index Values for Overweight at Age 35y. Am J Clin Nutr 1994;59:810-19.

12. Rising R. Determinants of Total Daily Energi Expenditure: Variability in Physical Activity. Am J Clin Nutr 1994;59:800-4.

13. Schulz LO and Schoeller DA. A Compilation of Total Daily Energi Expenditures and Body Weights in Healthy Adults. Am J Clin Nutr, 1994;60:676-81.

14. Williamson DF. Dietary Intake and Physical Activity as Predictors of Weight Gain in Observational, Prospective Studies of Adults. Nutrition Reviews 1996;54:S101-S109.

15. Rissanen AM. Determinants of Weight Gain and Overweight in Adult Finns. Eur J Clin Nutr 1991;45:419-430.

16. Prentice AM and Jebb SA. Obesity in Britain: Gluttony or Sloth? BMJ 1995;311:437-439.

17. BAPPENAS. Relevansi Paket Pelayanan Kesehatan Dasar Dalam Pencapaian Target Nasional dan Komitment Global. Jakarta 2004.
18. BAPPENAS. Indonesia Progress Report on the Millenium Development Goals. Jakarta 2004.

19. Suyono S. Kecenderungan Peningkatan Jumlah Penyandang Diabetes. Dalam: Soegondo S, Soewondo P, dan Subekti I. Penatalaksanaan Diabetes mellitus terpadu. Pusat Diabetes Melitus dan Lipid RSUP Dr. Ciptomangunkusumo. Jakarta; 2004. p. 1-5.

20. National Health and Medical Research Council. Economic Issues in the Prevention and Treatment of Overweight and Obesity. A Strategic Plan for the Prevention of Overweight and Obesity. Canberra: Australia Government Publishing Service; 1997. p. 85-95.

21. Levy E. The Economic Cost of Obesity: the French Situation. Int J of Obesity nad related Metabolic Disorders 1995;19:788-92.

22. Seidell $\mathrm{J}$ and Deerrenberg I. Obesity in EuropePrevalence and Consequences for the Use of Medical Care. PharmacoEconomics 1994;5 (Suppl 1);38-44.

23. Wolf AM and Colditz GA. The Cost of Obesity: the US Perspective. PharmacoEconomics, 1994;5(Suppl.1); 34-37.

24. Kayman S, Bruvold W, Stern JS. Maintenance and Relapse after Weight Loss in Women: Behavioral Aspects. Am J Clin Nutr 1990;(52): 800-7.

25. Pi-Sunyer FX. Medical Hazards of Obesity. Annals of Internal Medicine 1993;(119):655-660. 